\title{
Date-Randomization for NIGERIA_7576
}

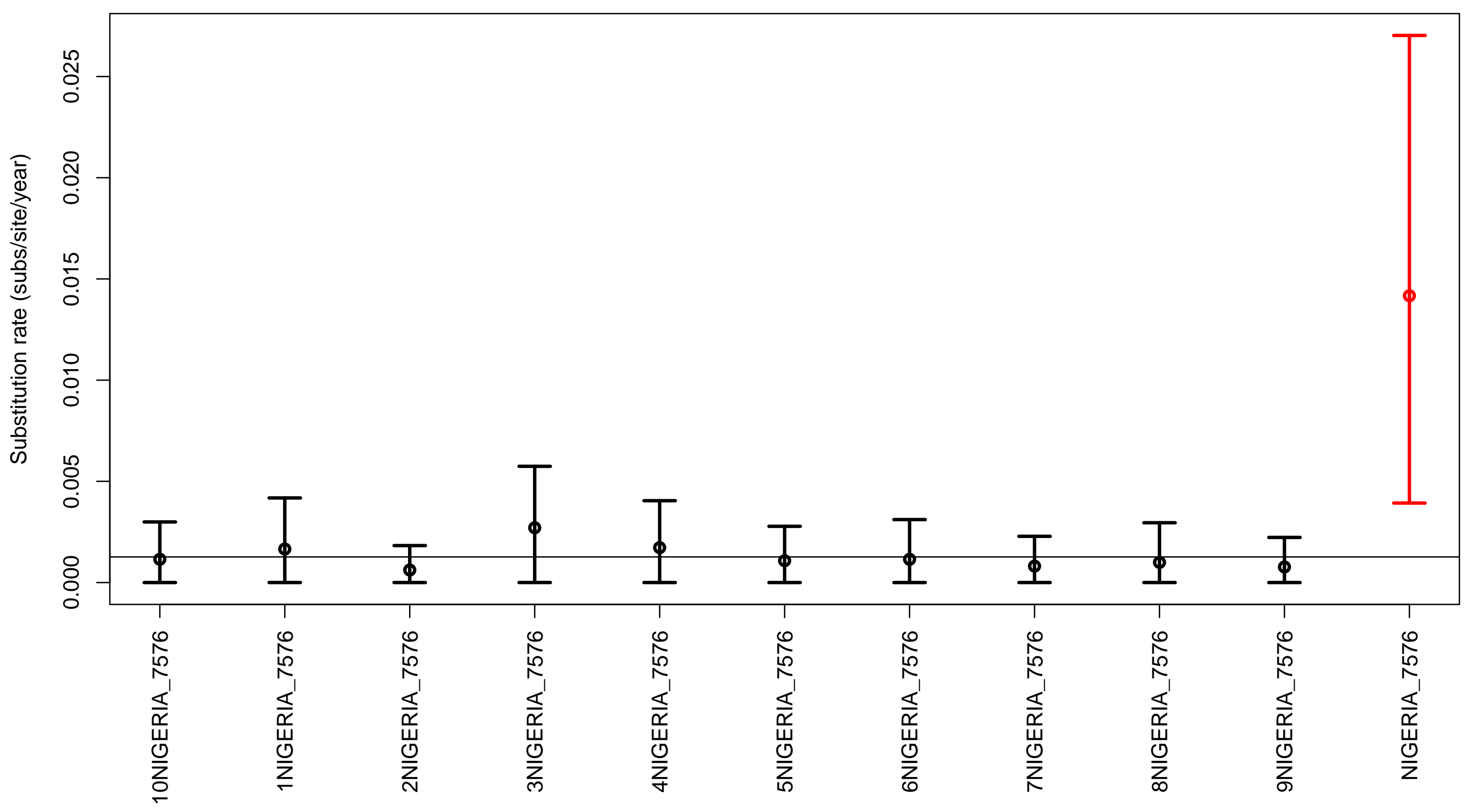

